\title{
Comparison of aggression among informal caregivers of psychotic patients according to their participation in Mental Health Association
}

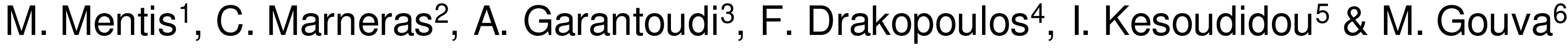

1.Social Service, University Hospital of Patras, 2.Pathological Clinic, University Hospital of Patras, ${ }^{3}$.Student of psychology at the Deree American College of Greece, ${ }^{4}$.Center for Educational and Counseling Support Arkadias, ${ }^{5}$ Emergency Department, University Hospital of Patras, ${ }^{6}$.Research Laboratory Psychology of Patients Families and Health Professionals, University of loannina - Greece

The vast majority of people with severe mental health problems reside with their informal caregivers, who are usually parents. Informal caregivers have to deal with a range of emotional problems, acceptance issues, stigma, burden and a number of problems stemming from the characteristics of the disease and their ability to handle the various symptoms.

Objectives: The purpose of this study was to compare the level of hostility among informal carers with chronic mental health problems who were self-help associations with those who were not. The specific aims of the research were to investigate whether hostility is influenced by caregivers' gender, kinship and years of care.

Materials and methods: The sample of the study was 416 informal caregivers of patients with chronic psychotic symptoms (psychosis and bipolar disorder). The sampling method was the avalance technique using "gatekeeper", who in this case were the mental health association managers and the mental health units. The survey was conducted in 2018. A written structured questionnaire with socio-demographic characteristics, as well as the Hostility and Direction of Hostility Questionnaire (HDHQ) scale was used.

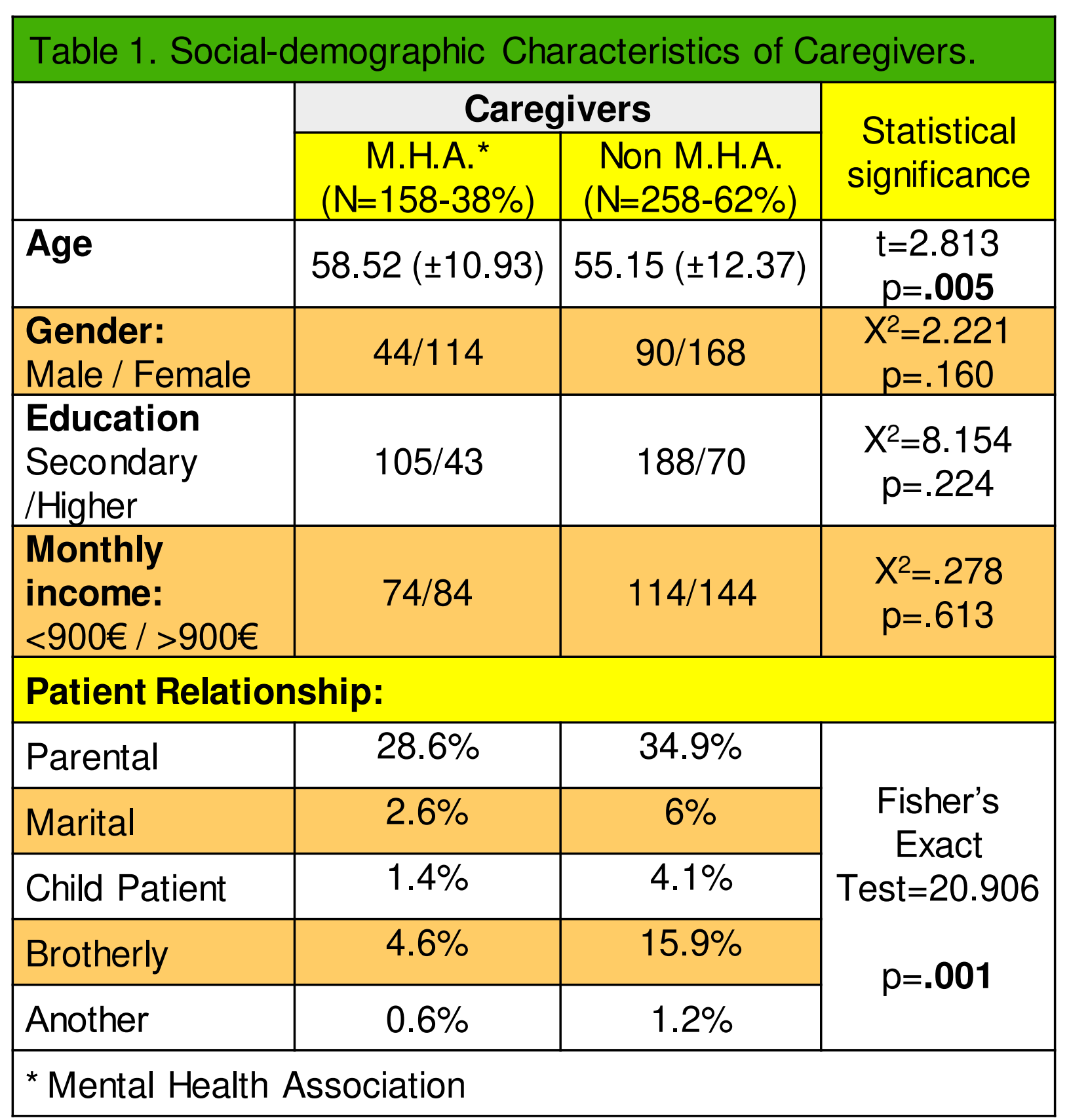

References

1. Brain, C., Kymes, S., DiBenedetti, D. B., Brevig, T., \& Velligan, D. I. (2018) Experiences, attitudes, and perceptions of caregivers of individuals with treatmentresistant schizophrenia: a qualitative study. BMC psychiatry, 18(1), 253.
Results:Table 1 presents the socio-demographic characteristics of the sample. Based on these data, it appears that the majority of the sample (62\%) was not affiliated with Mental Health Associations (M.H.A.). Most carers were women. The mean age of the sample was 56.43 years $( \pm 11.95)$. Concerning hostility, comparing the two groups of informal caregivers (Table 2) with the $t$ test showed that caregivers who were members of mental health associations exhibited lower levels for both extroverted and introverted hostility and overall hostility. However, a significant statistical difference $(p<0.01)$ was observed only in the subscale of impulsive aggression $(\mathrm{AH})$, whereas a marginal statistical difference between the two groups was observed both in the scale of extroversion aggression $(p=.051)$ and in total hostility $(p=.056)$.

Conclusion: The study showed that participation in self-help mental health association helps informal family caregivers of people with mental health problems contribute to reduced hostility, which contributes to maintaining a more stable family atmosphere with less stress and better quality of life for both people with chronic mental illness and their family caregivers.

\begin{tabular}{|l|c|c|c|}
\hline \multicolumn{3}{|c|}{$\begin{array}{l}\text { Table 2. Comparison of Average Hostility } \\
\text { Caregivers. }\end{array}$} & \multirow{2}{*}{$\begin{array}{c}\text { Statistical } \\
\text { significance } \\
\text { T Test (p) }\end{array}$} \\
\cline { 2 - 3 } $\begin{array}{l}\text { Hostility \& } \\
\text { Direction of } \\
\text { Hostility - } \\
\text { HDHQ }\end{array}$ & $\begin{array}{c}\text { M.H.A. }{ }^{*} \\
\text { Mean (SD) }\end{array}$ & $\begin{array}{c}\text { Non M.H.A. } \\
\text { Mean (SD) }\end{array}$ & .233 \\
\hline $\begin{array}{l}\text { Criticism of } \\
\text { Others (CO) }\end{array}$ & $6.46(2.17)$ & $6.72(2.21)$ & .004 \\
\hline $\begin{array}{l}\text { Acting-out } \\
\text { Hostility (AH) }\end{array}$ & $3.41(2.02)$ & $4.01(2.04)$ & .557 \\
\hline $\begin{array}{l}\text { Paranoid } \\
\text { Hostility (PH) }\end{array}$ & $2.53(1.71)$ & $2.64(2.13)$ & .153 \\
\hline $\begin{array}{l}\text { Self-Criticism } \\
\text { (SC) }\end{array}$ & $4.09(2.34)$ & $4.43(2.42)$ & .369 \\
\hline Guilt (G) & $2.62(1.71)$ & $2.78(1.77)$ & .051 \\
\hline $\begin{array}{l}\text { Extrovert } \\
\text { Hostility }\end{array}$ & $12.40(4.69)$ & $13.37(5.28)$ & .183 \\
\hline $\begin{array}{l}\text { Intrusive } \\
\text { Hostility }\end{array}$ & $6.71(3.78)$ & $7.21(3.71)$ & .056 \\
\hline Total Hostility & $19.11(7.41)$ & $20.59(7.99)$ & \\
\hline * Mental Health Association & & \\
\hline
\end{tabular}

2. Onwumere, J., Zhou, Z., \& Kuipers, O. B. E. (2018). Informal caregiving relationships in psychosis: reviewing the impact of patient violence on caregivers. Frontiers in psychology, 9, 1530.

3. Smith, L. M., Onwumere, J., Craig, T., \& Kuipers, E. (2018). Caregiver correlates of patient-initiated violence in early psychosis. Psychiatry research, 270, 412-417. 